\title{
PENERAPAN PROGRAM NGAQU (NGAJI ALQURAN) BAGI WARGA LAPAS KELAS II B TUBAN UNTUK MENINGKATKAN PEACEFULNESS OF SOUL
}

\author{
M. Fauzi \\ Fakultas Tarbiyah IAINU Tuban \\ Email : m.fauziiainutuban@gmail.com \\ Jamal Ghofir \\ Fakultas Tarbiyah IAINU Tuban \\ Email : legend_kaos@yahoo.co.id
}

\begin{abstract}
Abstrak
Peacefulness of soul atau ketenangan jiwa bagi warga lapas, khususnya lapas kelas II B Tuban sangatlah penting, karena keterbatasan ruang dan gerak akan sangat memungkinkan penghuninya untuk mengalami goncangan-goncangan psikologis/kejiwaan. Untuk mendapatkan ketenangan jiwa, perlu melakukan aktifitas yang dapat menenangkan jiwanya, dengan mendekatkan diri kepada Allah Swt, salah satunya dengan membaca AlQuran. Di dalam lapas kelas II B Tuban sudah di bentuk sebuah lembaga TPQ yang mana semua Pengajarnya merupakan warga lapas sendiri. Namun, Kenyataan di lapangan memperlihatkan bahwa para Pengajar yang keseluruhan berasal dari warga lapas, dalam mengajarkan Al-Quran belum mempunyai metode khusus untuk menunjang keberhasilan kegiatan mengaji AlQuran. Padahal kegiatan mengaji Al-Quran ini sangat penting bagi warga lapas untuk menciptakan ketenangan jiwa, maka diperlukan hal-hal yang dapat menunjang tercapainya tujuan kegiatan ini.

Berangkat dari persoalan di atas, maka pendampingan program NGAQU (Ngaji AlQuran) bagi para Pengajar TPQ di lapas kelas II B Tuban sangat relevan khususnya untuk Developing peacefulness of soul atau ketenangan jiwa bagi warga lapas kelas II B Tuban.
\end{abstract}

Kata Kunci: Taman Pendidikan Al-Qur'an, peacefulness of soul (ketenangan jiwa), NGAQU (Ngaji Al-Quran), Lapas II B Tuban

\section{PENDAHULUAN}

Jiwa merupakan kekuatan dalam diri manusia yang menjadi penggerak bagi jasad dan tingkah laku. Jiwa adalah seluruh aspek rohani yang dimiliki oleh manusia yang menjadi hakikat dari manusia, yang mendorong menjadi sebuah tingkah laku, seperti hati, akal pikiran, emosi, dan perasaan. Menurut imam Al-Ghozali, jiwa adalah jisim yang sangat halus yang mengetahui dan merasa yakni manusia-manusia dengan hakikat kejiwaannya.(Imam Ghazali, 1984:3) Jiwa inilah yang merupakan hakikat dari kemanusiaan. Maka agar kita tidak kehilangan hakikat kemanusiaan, kita harus senantiaa menjaga keseimbangan jiwa, membuat jiwa selalu tenang.

Peacefulness of soul atau ketenangan jiwa berkaitan erat dengan kesehatan jiwa, kesejahteraan jiwa, atau kesehatan mental. Karena orang yang jiwanya tenang dan tenteram berarti orang tersebut mengalami keseimbangan di dalam fungsi-fungsi jiwanya sehingga dapat berfikir positif, bijak dalam menyikapi masalah, mampu menyesuaikan diri dengan situasi yang dihadapi serta mampu merasakan kebahagiaan hidup. Seseorang yang ingin mendapatkan ketenangan jiwa, perlu melakukan aktifitas yang dapat menenangkan jiwanya, dengan mendekatkan diri kepada Allah Swt. Hal itu akan menambah keimanannya. Kepercayaan agama yang tinggi akan menimbulkan ketenangan jiwa. 
Orang yang beriman kepada Allah Swt akan melakukan hal-hal yang bisa mendekatkan dirinya dengan Allah Swt, salah satunya seperti membaca Al-Quran. Sesungguhnya membaca AlQuran dapat meneguhkan iman kepada Allah Swt, karena seseorang yang membaca Al-Quran beriman kepada Al-Quran, sedang seseorang yang beriman kepada Al-Quran berarti dia beriman kepada Tuhan yang mewahyukannya, yaitu Allah Swt. (Miftah,dkk. 2014: 9). Salah satu manfaat atau faedah ketika seseorang membaca Al- Quran yaitu memberi kedamaian, ketenangan dan melembutkan hati. Al-Quran dapat membawa kedamaian di hati para pembacanya. Siapapun yang sedang dilanda gelisah, maka bacalah ayat-ayat suci Al-Quran yang secara seketika akan melenyapkan gelisah itu. Hati kita yang berhias Al-Quran akan menjadi tenang dan tentram sebagaimana firman Allah dalam Qs. Ar-Rad ayat 28. Jadi, dengan membaca Al-Quran secara rutin merupakan bukti seseorang selalu mengingat Allah sehingga mengalami ketenangan jiwa.

Setiap orang menginginkan adanya ketenangan jiwa, termasuk warga lapas. Warga lapas sendiri merupakan warga yang sedang menjalani sanksi kurungan atau yang lainnya di lembaga pemasyarakatan (LP). Hidup di LP bukanlah sesuatu yang menyenangkan. Dengan keterbatasan ruang dan gerak akan sangat memungkinkan penghuninya untuk mengalami goncangan-goncangan psikologis/kejiwaan, mulai dari stres ringan sampai kepada tindakan yang paling mengerikan, bunuh diri. Kondisi ini jelas merupakan gejala-gejala ketidak-mampuan seseorang secara psikologi/kejiwaan dalam menghadapi cobaan hidup yang sedang menderanya. Keputusasaan yang mereka rasakan tak jarang turut memenjarakan kesadaran mereka bahwa, sebagai makhluk sosial mereka tetap memiliki tanggung jawab sosial baik kepada dirinya sendiri, keluarga, dan masyarakat secara luas.

Sedangkan menurut Harsono (1995 : 81), dalam bukunya yang berjudul "sistem baru pembinaan narapidana" menyatakan bahwa kehidupan di lembaga pemasyarakatan memberikan dampak dalam berbagai aspek seperti dampak fisik dan psikologis. Dampak psikologis yang dialami oleh narapidana merupakan dampak yang paling berat untuk dijalani. Dampak psikologis akibat hukuman LP tersebut antara lain kehilangan akan kepribadian, kehilangan akan keamanan, kehilangan akan kemerdekaan, kehilangan akan komunikasi pribadi, kehilangan akan pelayanan, kehilangan akan hubungan antar lawan jenis, kehilangan akan harga diri, kehilangan akan kepercayaan, dan kehilangan akan kreatifitas.

Permasalahan di atas sangat rentan dihinggapi oleh semua narapidana baik narapidana laki laki maupun narapidana wanita. Hal ini diperkuat dengan hasil penelitian yang dilakukan Bureau Of Justice Statistics yang menemukan fakta bahwa pada tahun 1998 sebanyak 23,6\% narapidana wanita teridentifikasi mengalami gangguan kesehatan mental dibanding pria yang hanya $15,8 \%$ bahkan setiap 1 dari 4 wanita di dalam LP teridentifikasi mengalami gangguan kesehatan mental.( The Sentencing Project, Research And Advocacy For Reform) Sedangkan pada tahun 2005 hampir sepertiga jumlah narapidana wanita $(73,1 \%)$ mengalami gangguan kesehatan mental dibandingkan pria yang hanya sekitar $55 \%$. Hasil penelitian ini memperjelas bahwa kecenderungan wanita menderita tekanan kejiwaan lebih besar daripada laki- laki, oleh karena itu, perlu adanya penanganan khusus dalam menyikapi permasalahan tersebut.

Lembaga Pemasyarakatan Kelas IIB Tuban merupakan lembaga milik pemerintah yang tugas utamanya menampung individu yang mengalami permasalahan hukum dan sekaligus bertugas memberikan pembinaan dari berbagai aspek seperti keterampilan, kesenian, dan intelektual. Di samping itu ada pula kegiatan pembinaan yang bernuansa keagamaan. Salah satu kegiatan keagamaan tersebut yaitu mengaji Al-Quran. Dalam pelakaan kegiatan mengaji Al-Quran ini, Lembaga Pemasyarakatan Kelas IIA Tuban telah menfasilitasi dengan adanya TPQ di dalam lapas sebagai tempat belajar atau kegiatan mengaji. Lembaga TPQ sudah terbentuk dengan baik dengan 15 Pengajar yang semuanya dari warga lapas sendiri. 15 Pengajar itulah yang membimbing seluruh warga lapas dalam melaksanakan kegiatan keagamaan ini.

Kenyataan lain di lapangan memperlihatkan bahwa para Pengajar yang keseluruhan berasal dari warga lapas, dalam mengajarkan Al-Quran belum mempunyai metode khusus untuk menunjang 
keberhasilan kegiatan mengaji Al-Quran. Kegiatan mengaji Al-Quran ini sangat penting bagi warga lapas untuk menciptakan ketenangan jiwa, maka diperlukan hal-hal yang dapat menunjang tercapainya tujuan kegiatan ini.

Berangkat dari persoalan di atas, maka pendampingan program NGAQU (Ngaji Al-Quran) bagi para Pengajar TPQ di lapas kelas II B Tuban sangat relevan khususnya untuk meningkatkan peacefulness of soul atau ketenangan jiwa bagi warga lapas kelas II B Tuban.

Tujuan diadakannya maka pendampingan program NGAQU (Ngaji Al-Quran) bagi para Pengajar TPQ di lapas kelas II B Tuban adalah untuk membekali para Pengajar TPQ metode membaca dan cara mengajar Al-Quran yang lebih baik dan lebih efektif.

\section{IMPLEMENTASI}

Kegiatan ini berupa pembelajaran Baca Al-Quran ditambah pemahaman makna bagi warga lapas Kelas II B Tuban

Adapun Bentuk kegiatannya adalah sebagai berikut:

1) Pembinaan bagi Pengajar Al-Quran di Lapas Kelas II B Tuban. Sebagaimana diketahui berdasarkan data dari bagian Bindik lapas kelas IIB Tuban bahwa di Lapas kelas II B Tuban telah berjalan sebuah program pembelajaran Al-Quran dengan 15 orang Pengajar Al-Quran yang mana Pengajar tersebut juga merupakan Warga binaan Lapas IIB Tuban. Tujuan dari pembinaan tersebut adalah agar memberikan bekal yang cukup memadai kepada para Pengajar tersebut, supaya dapat menjalankan tugas dengan baik dan akhirnya menghasilkan output yang baik pula.

2) Penerapan Hasil Pembinaan Pengajar:

Sesudah tahap pembinaan Pengajar berjalan maka tahap berikutnya adalah menerapkan hasil pembinan kepada warga lapas yang lain

Tahapannya dengan :

a. Placement class (pengelompokan) sesuai kemampuan untuk memudahkan penerapan sistema pembelajaran klasikal

b. Setiap kelas terdiri dari 15-20 orang dengan seorang Pengajar

c. Setiap tatap muka durasi waktu selama 1 jam dengan pembagian waktu:

- 5 menit Do'a pembuka

- 40 menit pembelajaran (buku Jilid/Al-Quran)

- 10 menit Hafalan Surat-surat pendek dan do’a

- 5 menit do'a penutup

Program NgaQu dengan paket 3T (Tahsin, Tahfiz dan Tafsir) Al-Quran bagi warga yang sudah khatam Jilid (Kelas Al-Quran) maka perlu ditingkatkan dengan pembinaan Tahsin (memperbaiki bacaan) juga perlu adanya pembinaan menghafal Al-Quran minimal surat-surat pendek (Juz 30) juga perlu memberikan kajian tafsir (pemahaman) supaya mereka memahami apa yang mereka baca dan dapat menghayati isi kandungan (makna) dari Al-Quran yang merupakan pengobat hati yang sedang gelisah dan diharapkan akan tercapai ketenangan jiwa yang berdampak pada pembentukan pribadi yang lebih baik yang merupakan salah satu tugas lembaga pemasyarakatan.

\section{a. Waktu Pelaksanaan}

1) Pelaksanaan Pembinaan Pengajar Al-Quran di lapas kelas IIB Tuban dilaksnakan sepekan sekali selama 6 pekan dengan durasi waktu sekitar 2 jam setiap tatap muka

2) Pelaksanaan Pembelajaran Al-Quran metode Tilawati, dan Tahsin dilaksanakan dalam sepekan 2 kali tatap muka setiap tatap muka durasi 1 jam (60 Menit) 


\section{HASIL DAN PEMBAHASAN}

Pembinaan Program NGAQU (Ngaji Al-Quran) bagi Pengajar Al Quran di lapas kelas IIB Tuban ini menggunakan metode Tilawati. Pembelajaran Program NGAQU (Ngaji Al-Quran) terdiri dari pembelajaran membaca Al-Quran dengan menggunakan jilid tilawati yang dilakasanakan setiap

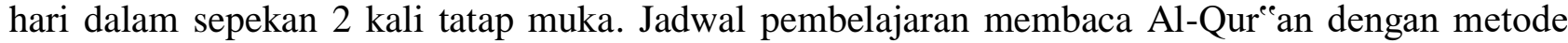
tilawati ini dilaksanakan dari pukul setengah delapan pagi hingga pukul sepuluh. Selain itu ada Program NGAQU (Ngaji Al-Quran) setiap kelasnya dibimbing oleh 2 orang Pengajar, satu Pengajar sebagai Pengajar inti dan satu orang lagi sebagai Pengajar pendamping.

Program NGAQU (Ngaji Al-Quran) menggunakan metode Tilawati menekankan aspek fashohah yang meliputi waqof, muroatul huruf wal harokat, muroatul kalimat wal ayat, aspek tajwid yang meliputi makhorijul huruf, sifatul huruf, ahkamul huruf, ahkamul mad wal qoshr, dan aspek suara dan lagu yakni kualitas vokal dan penguasaan lagu.

Pembelajaran Program NGAQU (Ngaji Al-Quran) menggunakan metode Tilawati, diawali dengan Pengajar memberi salam, kemudan Pengajar memotivasi peserta untuk semangat belajar. Setelah itu Pengajar dan peserta berdoa bersama sebelum pembelajaran dimulai yang dipimpin oleh salah seorang peserta. Setelah berdoa Peserta dan Pengajar klasikal bersama-sama sesuai jilid tilawati yang sedang dipelajari dengan menggunakan peraga tilawati. Pengunaan peraga tilawati ini dilakukan dengan 3 teknik yakni teknik pertama Pengajar membaca murid mendengarkan, teknik kedua Pengajar membaca murid menirukan, dan teknik ketiga Pengajar dan murid bersama-sama membaca. Setelah itu dilanjutkan dengan baca simak buku tilawati sesuai yang sedang dipelajari. Setelah selesai semua kemudian dilanjutkan dengan salam penutup. Dari awal pembelajaran sampai akhir pembelajaran membaca Al-Qurean dengan metode tilawati kesemuanya menggunakan lagu rost.

Asas Pembelajaran membaca Al-Quran dengan metode tilawati ini adanya keseimbangan antara pembiasaan melalui pendekatan klasikal dan kebenaran membaca melalui pendekatan individual dengan teknik baca simak. Sehingga pembelajaran membaca Al-Quran dengan metode tilawati menyenangkan dan cukup membantu dalam memahami bacaan-bacaan Al-Quran dengan lagu yang mudah ditirukan. Disamping menyenangkan namun tidak lepas dari keseriusan dalam pembelajaran sehingga apa yang disampaikan oleh Pengajar bisa dipahami oleh Peserta.

Disamping itu dalam buku tilawati dilengkapi juga dengan penjelasan tentang fashohah dan tajwid yang sangat memudahkan Pengajar untuk memahami dan mengajarkan kepada Peserta dengan baik dan benar. Selain itu, adanya penjelasan yang rinci dan contoh bacaan yang sesuai dengan sub bab materi membuat Pengajar mudah untuk mengajarkan. Apalagi dengan ditambah adanya tanda merah pada setiap kalimat yang mengandung materi pokok bahasan yang sedang dibahas membuat Peserta dapat memahami bacaan dengan baik.

\section{Proses Penerapan Program NGAQU (Ngaji Al-Quran) menggunakan Metode Tilawati dalam Pembelajaran di lapas kelas IIB Tuban}

Proses penerapan Program NGAQU (Ngaji Al-Quran) menggunakan Metode Tilawati dalam Pembelajaran di lapas kelas IIB Tuban diantaranya :

1) Kegiatan Awal

Pada kegiatan pendahuluan dalam pembelajaran Program NGAQU (Ngaji Al-Quran) menggunakan Metode Tilawati dalam Pembelajaran di lapas kelas IIB Tuban dilakukan oleh Pengajar diawal pembelajaran. Kegiatan ini di,ulai dengan Pengajar memberi salam dan Peserta menjawab salam secara berbarengan, kemudian salah seorang Peserta memimpin berdoa lalu Pengajar menanyakan kabar dengan semangat dan ceria dengan bahasa bahasa Indonesia dan bahasa Jawa, "Bagaimana kabarnya hari ini ?" kemudian Peserta menjawab "Baik Alhamdulillah", "Pripun kabare dinten niki ?" kemudian Peserta menjawab "Alhamdulillah sae". Setelah mengucapkan salam dan berdo "e kemudian Pengajar mengawali dengan surat Al-fatihah sebagai pembuka. 
Setelah selesai dan Peserta terkondisikan, Pengajar memberikan pelajaran dengan teknik dan variasi metode pengajaran.

2) Kegiatan Inti

Program NGAQU (Ngaji Al-Quran) menggunakan Metode Tilawati dalam Pembelajaran yakni melalui pendekatan klasikal/ langsung dan pendekatan individual dengan teknik baca simak. Metode ini dikembangkan atas dasar asumsi bahwa proses belajar bahasa kedua atau bahasa asing sama dengan belajar bahasa ibu, yaitu dengan penggunaan bahasa secara langsung dan intensif dalam komunikasi, dan dengan menyimak dan berbicara. Sedangkan mengarang dan membaca dikembangkan kemudian (Achoita, 2018:22).

Pada pendekatan klasikal proses belajar mengajar dilakukan dengan cara bersama-sama atau berkelompok dengan menggunakan peraga. Pada pendekatan klasikal ini menggunakan tiga teknik. Teknik pertama yakni dengan Pengajar membaca Peserta mendengarkan, teknik kedua Pengajar membaca Peserta menirukan dan teknik ketiga Pengajar dan Peserta membaca bersama-sama.

Ketiga teknik tersebut tidak digunakan semua pada saat praktel klasikal, namun disesuaikan dengan jadwal atau perkembangan kemampuan Peserta. Pengajar membacakan setengah halaman sedangkan Peserta menyimak sambil menandai waqof dan ibtida. Kemudian Pengajar mengulangi bacaan diatas tiap waqof dan Peserta menirukannya. setelah semua Peserta sudah siap untuk belajar. Peserta memperhatikan Pengajar yang berada di depannya. Untuk kemudian Pengajar memulai membaca tulisan yang ada pada peraga Tilawati yang ada di depan. Pengajar membacakan 4 halaman pada setiap kali pertemuan. Setiap halaman yang ada pada peraga tilawati dibaca menggunakan teknik yang sudah di sesuaikan pada metode tilawati. Sebagai contoh seorang pengajar saat mengajar membaca Al-Quran dengan metode tilawati jilid 2. Pada saat itu beliau membacakan peraga tilawati halaman 4 sampai dengan 8 .

Pertama-tama beliau membaca peraga tilawati jilid 2 dari awal hingga akhir dan murid mendengarkan dengan tetap menyimak peraga yang ada di depan. Setelah itu ibu Supriyani kemudian membacakan lagi dari atas lalu kemudian ditirukan oleh Peserta per barisnya samapai akhir. Ketiga teknik tersebut tidak digunakan semua pada saat praktel klasikal, namun disesuaikan dengan jadwal atau perkembangan kemampuan Peserta. Pengajar membacakan setengah halaman sedangkan Peserta menyimak sambil menandai waqof dan ibtida'. Kemudian Pengajar mengulangi bacaan diatas tiap waqof dan Peserta menirukannya. setelah semua Peserta sudah siap untuk belajar. Peserta memperhatikan Pengajar yang berada di depannya. Untuk kemudian Pengajar memulai membaca tulisan yang ada pada peraga Tilawati yang ada di depan. Pengajar membacakan 4 halaman pada setiap kali pertemuan. Setiap halaman yang ada pada peraga tilawati dibaca menggunakan teknik yang sudah di sesuaikan pada metode tilawati. Sebagai contoh seorang pengajar saat mengajar membaca Al-Quran dengan metode tilawati jilid 2.

Pada saat itu beliau membacakan peraga tilawati halaman 4 sampai dengan 8. Pertama-tama beliau membaca peraga tilawati jilid 2 dari awal hingga akhir dan murid mendengarkan dengan tetap menyimak peraga yang ada di depan. Setelah itu pengajar membacakan lagi dari atas lalu kemudian ditirukan oleh Peserta per barisnya samapai akhir. Tilawati ini bersifat kelompok bukan individual.

Kelompok belajar metode Tilawati dibagi menjadi 3 kelompok yakni kelompok Tilawati jilid 1, kelompok Tilawati jilid 2 dan kelompok Tilawati jilid 4. Pada kelompok Tilawati yang diampu oleh Uatadz Fauzi baca simak pada tilawati jilid 2 sudah sampai pada halaman 30. Jumlah Peserta yang sudah tilawati 2 ada 8 orang yakni Supardi, Minto, Ari, Teguh, Prasetyo, Karto, Jauhari dan Siswo. Proses belajar membaca Al-Quran dengan metode tilawati pada pendekatan baca simak ini setiap Peserta akan membaca per baris sesuai urutan duduknya masing-masing. Sebelum mereka mulai membaca terlebih dahulu Pengajar mencontohkan seperti yang sudah ada pada peraga tilawati. Dengan menggunakan teknik yang sama, Ustadz Fauzi meminta Pesertanya untuk dapat membuka tilawati pada halaman 33. Kemudian beliau meminta Pesertanya untuk dapat menyimak dengan menunjuk jarinya pada setiap bacaan yang akan di contohkannya. Setelah semua siap beliau 
memulai membacakan dari awal kalimat sampai akhir. Kemudian masih pada posisi yang sama beliau melanjutkan untuk memberi contoh ulang tiap barisnya yang di tirukan oleh Pesertanya sampai selesai. Kemudian barulah pendekatan baca simak dilakukan.

Baca simak pada saat itu dimulai dari Supardi yang membaca baris pertama kemudian yang lain menyimak, lanjut baris kedua yang dibaca oleh Minto yang lain menyimak, lanjut baris ketiga dibaca oleh Ari yang lain menyimak dan begitu seterusnya sampai Peserta yang berurutan ke delapan. Kemudian kembali lagi pada Peserta yang berurutan yang pertama namun membaca baris kedua karena sudah membaca pada baris pertama. Begitu seterusnya sampai baris halaman tersebut habis dibaca oleh semua Peserta.

Kelompok Tilawati jilid 4 hampir sama dengan kelompok tilawati jilid 2, yaitu kegiatan inti dimulai dengan membaca peraga tilawati yang di contohkan oleh Pengajar. Setelah peraga tilawati selesai maka dilanjut dengan dengan baca simak. Untuk kelompok tilawati jilid 4 ini diampu oleh Ustadz Fahmi. Baca simak pada kelompok tilawati jilid 4 ini sudah sampai pada halaman 7. Pada halaman 7 ini terdapat pokok bahasan yang harus dikuasai Peserta yakni penjelasan tentang mad Jaiz. Dimana setiap mad ada hamzah dalam satu kalimat dibaca 5 harokat. Setiap huruf mad jaiz pada halaman 6 ditandai dengan tinta merah. Hal ini dapat memudahkan Pengajar dan Peserta dalam memahami pokok bahasan tersebut.

Adanya perbedaan pokok bahasan dalam buku tilawati disesuaikan dengan tingkat jilid tilawati. Semakin tinggi jilid tilawati yang sedang dibaca maka semakin banyak pokok bahasan yang sudah dipelajari. Masing-masing jilid pada tilawati sudah terdapat pokok bahasannya sendiri.

Penjabaran di atas menunjukkan bahwa kegiatan inti dalam pembelajaran membaca Al-Quran dengan metode Tilawati di Lapas IIB Tuban sudah disesuaikan dengan buku pedoman Tilawati, yaitu adanya keseimbangan antara pembiasaan melalui pendekatan klasikal dan kebenaran membaca melalui pendekatan individual dengan teknik baca simak.

Kegiatan inti ini sudah disesuaikan dengan tahap pembelajaran, yaitu kegiatan inti Pengajar sudah melatih Peserta dari segi pengetahuan, sikap dan ketrampilan dalam belajar membaca AlQuran dengan metode Tilawati. Dari segi pengetahuan Pengajar mengenalkan bacaan huruf yang benar kepada Peserta dengan mencontohkan secara langsung dan Peserta menirukan. Selain itu Peserta juga dibekali dengan pengetahuan fashohah dan tajwid. Dari segi ketrampilan Peserta dibiasakan untuk dapat membaca dengan lagu rost. Sedangkan dari segi sikap, Peserta dapat membaca sesuai urutannya masing-masing dengan tertib dan rapi.

3) Penutup

Kegiatan penutup dalam pembelajaran membaca Al-Quran dilakukan dengan mengadakan evaluasi. Evaluasi dilakukan secara kelompok dengan prosesi tanya jawab terhadap pokok bahasan yang telah dipelajari. Selain itu Pengajar dapat memperhitungkan berapa persen tingkat pemahaman Peserta untuk dapat layak naik ke halaman berikutnya. Selanjutnya kegiatan ditutup dengan bacaan hamdallah bersama-sama.

\section{Prestasi Peserta Program NGAQU (Ngaji Al-Quran)}

Berdasarkan hasil angket yang dibagikan kepada 30 peserta Program NGAQU (Ngaji AlQuran) menggunakan Metode Tilawati, setelah mengikiti pendampingan menunjukkan bahwa adanya program NGAQU ini dapat meningkatkan ketenangan jiwa. Peserta merasa dengan mereka dapat membaca dengan baik dan benar dapat menambah ketenangan batin sehingga mampu mendatangkan pikiran positif. 


\section{DAFTAR RUJUKAN}

Abdurrahim Hasan dan Muhammad Arif dkk. Strategi Pembelajaran Alquran Metode Tilawati.

Ana Achoita. 2019. "BAHASA ARAB DAN METODE PENGAJARANNYA". Tadris : Jurnal $\begin{array}{llllll}\text { Penelitian Dan Pemikiran Pendidikan Islam } 12 & \text { (2), }\end{array}$ https://ejournal.iainutuban.ac.id/index.php/tadris/article/view/20.

Daradjat, Zakiyah. 1982.Kesehatan Mental. Jakarta: GunungAgung.

Ghazali, Imam. 1984. Keajaiban Hati. (terj.) Nur Hichmah, dari Ajaib Al-Qolb, Jakarta: Tirta Mas.

Imam Al-Ghazali. 1984. Ihya Ulumuddin Bab Ajaibul Qolbi Terj. Ismail Yakub. Jilid 4. Jakarta: Tirta Mas.

Irwanto,dkk. 1991. Psikologi Umum. Jakarta: PT Gramedia Pustaka Utama.

Kartono, Kartini dan Jenny Andari. 1989. Hygiene Mental dan Kesehatan Mental Dalam Islam. Bandung: Mandar Maju.

Kulsum, Umi. 2015. jurnal dengan judul ketenangan jiwa dalam keberhasilan proses pendidikan remaja.

Nasih, Ahmad Munjin. 2009. Metode Dan Teknik Pembelajaran Pendidikan Agama Islam. Bandung : PT Refika Aditama.

Soemanto, Wasty. 1988.Pengantar Psikologi. Jakarta: Bina Aksara.

Ubbiyati, Nur. 1997. Ilmu Pendidikan Islam. Bandung: Pustaka Setia. 